\title{
A simple reflection on climate change
}

\author{
Afonso Lopes de Barcellos', Renata da Silva Pereira Saccol", Nathália Leal de Carvalho'"', \\ Luana Filippin Rosa ${ }^{\mathrm{V}}$
}

\section{Abstract}

In order to discuss climate change and our role, this literature review was developed. The term climate change, climate change or climate change refers to global-scale climate change or Earth's regional climates over time. These variations refer to changes in temperature, precipitation, cloudiness and other climatic phenomena in relation to historical averages. Such variations can alter climatic characteristics in a way to change their didactic classification. These changes can be caused by processes internal to the Earth-atmosphere system, by external forces, or by the result of human activity. Therefore, it is understood that climate change can be either an effect of natural processes or arising from human action and so one should keep in mind what kind of climate change is being referred to.

Keywords: Global warming; Carbon dioxide; Sustainability 


\section{Introduction}

Climate change is happening now and is no longer a myth! Majority of population is aware that Earth it's getting warmer, but we really know what's causing this effect, and what is its impact?

The climate changes are alterations that occur in the general climate of planet Earth. These changes are verified by means scientific records in the average values or deviations from the mean, calculated over the years, and are produced at different time scales in one or several meteorological factors, for example: maximum and minimum temperatures, rainfall indexes (rains), ocean temperatures, cloudiness, relative humidity of air, etc., and are caused by natural phenomena or by human actions. In the latter case, such changes it has been caused since the Industrial Revolution (18th century), moment time it significantly counted air pollution (TAMAIO, 2013).

Nowadays, climate changes have been target of several discussion and scientific research. Climatologists have verified that in recent decades, there was a significant increase in global temperature, phenomenon known as global warming. This phenomenon, generated by the increase of the air pollution, has provoked the ice melting of the polar caps and the increase in the level of water of the oceans. Another problem that we can mention is the desertification process has also increased in the last decades due to these changes (KLINK, 2013).

Thus we know that it is of extreme importance the preserve natural resources, mainly in reference of climate change, which is the objective of the work; we make a based reflection on the current state of the art literature to discuss about this so comprehensive and important subject in the present days and would rethink about our attitudes.

\section{What are climate change}

In a simple way for understanding, can be known also as global warming, because it happens is due to the global average temperature increase. The increasing of emissions of greenhouse gases in atmosphere (mainly $\mathrm{CO}^{2}$ ) are holding the heat in the Earth's atmosphere. This directly affects the global climate systems, generating, from unexpected rain to extreme heat waves. The Earth has already passed many times by periods of oscillations between heating and cooling - and associated climate change. What the researchers are worried about is that the warming process is happening much accelerates than before, and that this warming is caused by the increased levels of man-made emissions (MMA, 2017).

The planet earth is already almost a degree Celsius warmer than it was before the industrial revolution. This may seem like little, but it can have devastating consequences for the land and the living conditions of millions of people around the world. Researchers warn that we need to contain this increase to a maximum of two degrees from the 1990 level, the base level considered in the international climate negotiations (MARENGO, 2006).

The National Aeronautics and Space Administration
(NASA) disclosed in mid 2010 that the hottest decade ever recorded occurred in 31 December 2009 since 1880, year in which the modern measurement of temperatures around Earth began. In this decade also there were the two years of greatest heat intensity in more than a century, since 2005 the hottest year of the period, and 2009, the second (GREENPEACE, 2017).

Such fact was verified by the Intergovernmental Panel of Climate Change (IPCC) of ONU, that the increase of the temperature of the planet is a consequence of human actions,

Tal fato foi constatado pelo Painel Intergovernamental de Mudanças Climáticas (IPCC) da ONU que o aumento da temperatura do planeta é consequência de ações humanas, especially those dating after the Industrial Revolution, since the 18 th century. This promoted a technological leap forward, as well as the growth of civilizations like never before. On the other hand, boosted an unpublished and dangerous rate of emissions of gases, accelerating processes of pollution and environmental degradation (MAREGO, 2006).

Our industry grew based on the burning of fossil fuels such as oil and coal, two sources of energy found in the environment whose heat moves power plants, industries and economies. It happens that, the burning of these fuels releases gigantic volumes of $\mathrm{CO} 2$ into the air. Thus, this uncontrolled exploitation added with the deforestation of forests also somatized others million tons of these gases in the atmospheric air (TAMAIO, 2013).

CO2 is part of the Earth's atmosphere and forms a protective cover around the planet Earth, which helps to maintain the planet's temperature adequate for the maintenance of life - including human. This process is called greenhouse effect. The problem, therefore, it is not the natural mechanism itself, but yes, the interference of man. The extra volume of $\mathrm{CO} 2$ and others gases, such as methane, which were to the atmosphere starting from the Industrial Revolution, spread the cover, in a way that the terrestrial temperature passed on to rise dangerously (MMA, 2017).

We can go back? I believe that to a certain degree, not, at least in the short term. But the cost of development made anyway is too high for future generations, and a response must be given immediately. Do we need to leave that cover that covers the less thick planet? Or at least we can try to keep her the way it is today? The longer we take and take longer to account for our actions and implement some solutions, worse will be the future of the planet and the future of the next generations to come... dealing with such a situation will be increasingly expensive and much more difficult (CARVALHO \& BARCELLOS, 2012).

Thus, the sooner we let beside the coal and oil, or at least reduce its use and e invest in renewable energy sources, conserve their forests, rethink farming practices, invest in mobility and protect their oceans.

We have numerous promising sources of renewable energy such as the sun, the wind, the oceans and the biomass, not we need more to invest in mills coal and nuclear, and yes we should invest in alternatives to reduce the consumption of fossil fuels by cars, aircraft and 
ships. We need a diversified energy matrix, planned in compliance with human and environmental rights, and of

Precisamos de uma matriz energética diversificada, planejada em observância aos direitos humanos e ambientais, and energy efficiency, to stop throwing energy and money away and make the most of the energy produced (MMA, 2017).

Cities also play a key role in this process. They need intelligent and efficient transport systems, with collective transport of quality and restriction to the use of individual motorized transport. Currently, this transportation sector represents for a quarter of total global energy consumption, mainly in developing countries, such as Brazil. That is why it is extremely important that the means of transport that still run on the streets emit as little $\mathrm{CO} 2$ as possible, also contributing to the microclimate of cities (KLINK, 2013).

With all this pressure of consumption growing by fossil fuels has already until the Arctic, considered the air conditioning of the planet. With these changes, warming in the region happens twice as fast as the rest of the planet. Over the past three decades, it is estimated that $75 \%$ of the Arctic ice has disappeared. As if it was not enough the threat to this very important ecosystem, big oil companies are on an irresponsible mission to prospect for oil in their waters, taking advantage of its melting and accelerating its destruction (GREENPEACE, 2017).

Our rulers must move efforts to keep the forests standing and preserve the oceans, two importants sinks of $\mathrm{CO} 2$ that are under heavy threat.

The Earth needs, above all, that we all want to make the change, from the most common citizens to the ones who run countries and companies. Now is the time for action. Just so, the next billion people on earth will be grateful.

\section{Main Causes}

There are natural causes that accelerate climates changes, but the industrialization process is behind much of the recent and rapid acceleration of global warming. The needs of the populations lead to deforestation, the burning of fossil fuels and intensive agriculture. All these activities release greenhouse gases into our atmosphere - such as $\mathrm{CO} 2$, nitrous oxide and methane.

These gases trap the heat of the sun on the planet, making it difficult to reflect back into space. Such effect causes the Earth's atmosphere to warm up, which is called the greenhouse effect. In just 200 years, the $\mathrm{CO} 2$ concentration in our atmosphere has increased by $30 \%$.

\section{Main Effects}

Global warming can intensify climatic events such as droughts, hurricanes, floods and storms, raise ocean levels, change the rainfall regime and thus impact agriculture, urban occupations, use of water resources, the energy matrix , causing immeasurable economic and social damages. In this respect, are urgent the acctions to mitigate climate change by reducing carbon emissions and other greenhouse gases, as well as provided the means for society to adapt to the effects of these changes, particularly those plots most vulnerable to extreme events (TAMAIO, 2013).

Who has not heard about the emission of causers greenhouse gases and the possible deleterious impacts on the planet. However, majority countries still do not have an efficient plan to reduce the damage caused and either efficient strategies to reduce the emissions of these gases together atmosphere.

Disclosed on March 30, 2014, a report by the Intergovernmental Panel on Climate Change (IPCC) brought catastrophic predictions on the future of the Earth by the year 2100, and also cites that, even if the emission of greenhouse gases decreases, the Earth will continue to suffer from the residual damages of the impacts suffered and consequently we will have to learn to cope with the gradual increase of the temperature (MMA, 2017).

Are mentioned as being hit hardest by climate change, probably tropical countries, such as Brazil, which may suffer from flooding, due to the intensification of the storms, and long periods of drought. Faced with these two situations, livestock and agriculture may be harmed, as well as the survival of several species.

Os níveis de impactos gerados pelas mudanças climáticas dependem da taxa de aumento da temperatura da Terra. Thus, a degree of increase will have a serious ecological impact and could cost the world 210 trillion reais, it is estimated. This change will make some regions more humid, and some warmer. Sea levels will rise as glaciers melt, while some regions are more at risk from hot flashes, drought floods and natural disasters. Such fact could ruin food chains and ecosystems, putting entire species at risk of extinction (GREENPEACE, 2017).

A planet with a higher temperature can unbalance Earth's ultra-sensitive climate system. Generating as a consequence, the melting ice of the poles, raising the average level of the oceans, threatening coastal populations; storms become more frequent, intense and dangerous, as well as heat extremes waves or cold ; biomes are threatened by changes in the rainfall system, such as the Amazon. As a consequently, populations that are already vulnerable are left with the rope their necks, suffering impacts on the most diverse branches, such as food production, water supply and housing.

Besides that, some regions will could be affected by the large amount of rainfall, which could cause constant landslides and increased flooding. Another worrying question concerns the coastal areas, which will be most impacted by sea level rise,coming thanks to the melting of the glaciers caused by the increase in the average temperature of the planet.

The dry areas of the planet will suffer even more from drought. Thus, potable water, which is already scarce in some regions of the world, could be a reason of death and political disputes, due to their scarcity, and with the increase of dry periods, the occurrence of fires may be more frequent, which generates loss of biodiversity 
and threatens the life of the population (CARVALHO, et al., 2014).

Faced with such a catastrophic situation, it is not difficult to conclude that diverse species of plants and animals will go extinct. Fact that we can already observe nowadays. As well as, food production may decrease, once any climate change directly affects the cultivation of several species. Thereby, a difficulty may occur in accessing food, not only in combination with low production, but also because of the possible rise in prices (CARVALHO \& BARCELLOS, 2015).

Even though inevitable some of the facts reported, the decreased of the emission of greenhouse gases is necessary so that the intensity of these problems is diminished. It is fundamental that all countries around the globe are united to take actions that can contribute to the population to face all the adversities that are to come (CARVALHO, et al., 2015).

These changes have been causing had severe impacts under people's living and working conditions, thus as on wildlife and the environment. We can cite China, for example, where natural catastrophes hit 24.89 million hectares of plantations in 2014, of which 3.09 million hectares were destroyed, while drought caused direct economic losses of 83.6 billion yuan - more than 40 billion reais. Other example is Turkey, where a delay in the harvesting period in the Black Sea region in 2014 has caused Turkish tea growers to suffer $15 \%$ annual production losses due to heavy frost. In general, natural disasters that occurred in the last decades have already cost more than $\mathrm{R} \$ 8.4$ trillion to the world. Forest fires continue to threaten species that are already in danger, while the changes in climate and habitat take animals out of protected areas in search of water and habitable areas (GREENPEACE, 2017).

\section{How can each of us contribute?}

Each of us can try to limit or reduce the emission of greenhouse gases by opting to use the natural resources sustainably in our daily activities, thus, we have a chance to reduce the rhythm of increase of the temperature of the planet. But for this we need to awareness us about our use of resources in our day to day and act on climate change, helping to build a better future for our planet (CARVALHO, et al., 2015).

The scientific community warns that to achieve a balanced of GEE concentration in atmosphere, avoiding the pessimistic forecasts, is fundamental the drastic emission reduction. Thus, the main solution pointed out, and that seems global consensus, is that the world has to cut drastically the amount of greenhouse gases emitted daily into the atmosphere. For scientists, this amount should be at least $50 \%$ of global carbon dioxide emissions reduction by 2050 compared to 1990 levels (TAMAIO, 2013).

Scientists also warn that the longer postpone this moment, the worse the consequences for all living beings. And that decision-makers must take concrete and effective measures to address the seriousness of the problem. What happens is that there is a mismatch between science and global political action. On the other hand, to approach solutions to the anthropic cause of Climate Change, predominates a faith in the potential of technical-scientific progress, which for many is considered a naive and even illusory perception (KLINK, 2013).

Brazilian Environmental Education (EA) has several legal instruments, such as: the National Environment Policy (PNMA), which it established in 1981, in the legislative scope, the recommendation of inclusion EA in all levels of education; the Federal Constitution, in 1988, which established, in item VI of article 225, the need to "promote $\mathrm{EE}$ at all levels of education and public awareness for the preservation of the environment"; the National Environmental Education Policy (PNEA), approved in 1999, institutes the EA, promotes the creation of state and municipal policies in much of the national territory, in addition to Decree No. 4281 of June 25, 2002, which regulated it ; the National AE Program (1994, 2003 and 2005) which presents action plans, principles and guidelines for various social actors and contexts. In the non-governmental scope, we have the Environmental Education Treaty for Sustainable Societies and Global Responsibility, Agenda 21 and the Earth Charter, all elaborated in 1992, at the Global Forum (CARVALHO, 2015).

The interpretation and problematization of the causes and consequences of Climate Change in the conceptual field and in the practical making of EA in Brazil are still emerging. There is a set of pedagogical experiences, deliberations and proposals of EA, but isolated, that still do not allow to affirm, in a safe way, what are the placements and suggestions presented by the EA to face the phenomenon. We can verify that there is no a referential to be proposed as a instrument for dialogue to for a construction together with the other social actors involved(organized civil society, scientists, businessmen, governments, politicians, public managers, legislators and the media) about the issue of climate in Brazil (TAMAIO, 2013).

Greenpeace suggests some actions that can help with in these questions, issues as: investing in a smart and sustainable energy policy, the new renewable sources can supply half the world's demand by 2050; encourage the renewable energy sector: the generation and energy efficiency industry has the capacity to open 8 million jobs worldwide by 2030; to clear deforestation in the world, the felling and burning of tropical forests throw 5.1 billion tons of carbon per year into the atmosphere; only in Brazil, the volume is 1.26 billion tons per year; conserve the oceans and the seas absorb $\mathrm{CO} 2$ from the atmosphere, but they have a limit.

Destined $40 \%$ of the oceans to conservation units helps to keep them healthy, in order to fulfill this task; adapting the mobility of cities so that they provide efficient public transport and safe and comfortable displacements to the peoples., in order to reduce dependence on the use of cars and the burning of fossil fuels; the Brazilian fleet of automobiles grows every year, but the vehicles that are sold here consume more fuel and emit more greenhouse gases compared to Europeans. To increase the efficiency stan- 
dards of vehicles circulating in Brazil, outdated in relation to Europe, the origin of most of the automakers operating in the country; the Arctic is responsible for keeping the world's temperature stable. Creating a sanctuary in the uninhabited area Arctic and banning oil exploration and industrial fishing are the only actions that can prevent a catastrophe in the region (GREENPEACE, 2017).

In the question of renewable energies, the world consumed almost $80 \%$ of fossil energy in a total of 10.2 billion tonnes of oil equivalent of the world energy matrix in 2001. The main one is oil ( $35 \%$ of the total), but the share of coal $(23 \%)$ and natural gas $(22 \%)$ are also quite significant. Nuclear energy, also non-renewable, contributed about $7 \%$. Renewable sources contributed for the remaining $13 \%$. However, just under half of this parcel, $9 \%$ of the world total corresponded to traditional biomass, basically to burned wood in a primitive way. Only $4 \%$ of the world energy matrix was supplied with hydroelectric energy $(2 \%)$ and other "modern" options (2\%), such as wind, solar and biofuels (GOLDEMBERG; LUCON, 2007).

Energy consumption is very different between developed countries (from the Organization for Economic Cooperation and Development - OECD) and developing countries (called non-OECD countries), both in terms of quantity and quality. Thus:

- Developed countries consume almost five times more than the developing ones per inhabitant: 4.7 against 0.95 per capita;

- In the developed world, live just over 1 billion people, which consume 83 percent of their energy from fossil sources, more $11 \%$ of electricity of nuclear origin; only $6 \%$ of the energy is renewable;

- In developing countries, live almost 5 billion peoples, which utilize $22 \%$ renewable energy, mainly biomass (about $19 \%$ of the total); nuclear power is still few developed and fossil fuels predominate.

\section{Final Considerations}

Global warming is a reality and, if nothing is done, it will have catastrophic consequences for biodiversity and for mankind. That is why we must become aware of and reduce both our emissions and pressure governments and companies to reduce greenhouse gas emissions as quickly as possible.

For such, we must gradually put aside coal and oil and invest in renewable energy sources, conserve their forests, rethink farming practices, invest in mobility and protect their oceans. This is a strategy not only to reduce emissions of greenhouse gases, but to consolidate economic growth based on technologies that do not harm the planet

A considerable effort has been made by many countries to "clean" impurities from fossil fuels, but this can not solve the problem of climate change. $\mathrm{CO} 2$ capture (and launching in underground deposits) is complex, expensive and limited to a few processes.

Above all, doesn't reduce the extraction patterns of the resources present in the planet. Renewables avoid all these problems because they emit very little carbon in their life cycle and are practically inexhaustible. Moreover, emit much less local pollutants and generate many jobs (biomass generates 150 times more jobs per unit of energy than oil; solar energy even more).

\section{Referências}

CARVALHO, N.L. Percepção ambiental de alunos do Ensino Fundamental no Município de Tupanciretã - RS. Trabalho de conclusão de curso. Curso de Especialização em Educação Ambiental, UFSM. p.50. 2015.

CARVAlHO, N, L. et al., Desenvolvimento sustentável $x$ desenvolvimento econômico. Revista Monografias Ambientais, UFSM Santa Maria, v. 14, n. 3, p. 109-117, Set-Dez. 2015.

CARVALHO, N.L et al., Reutilização de águas residuárias. Revista Monografias Ambientais, UFSM Santa Maria V. 14, N. 2, p. 3164 - 3171, Março, 2014.

CARVALHO, N.L. \& BARCELlOS, A.L. - Adoção do Manejo Integrado de Pragas baseado na percepção e educação ambiental. Revista Eletrônica em Gestão, Educação e Tecnologia Ambiental,/UFSM Santa Maria. v(5), n5, p. 749 - 766, 2012.

GOLDEMBERG, J. \& LUCON, O. Energias Renováveis: um futuro sustentável. Revista USP, n. 72 p. 6-15. São Paulo, 2007.

GREENPEACE. Energias renováveis contra o aquecimento global. Disponível em: $<$ http://www.greenpeace.org/brasil/pt/ O-que-fazemos/Clima-e-Energia/?gclid=EAIaIQobChMI_ dKygs_w1wIVUAmRCh36eg9JEAAYAiAAEgI0Q_D_ BwE>. Acesso em 04 de dezembro de 2017.

INTERNATIONAL Energy Agency. Energy Balances of non-OECD Countries 2000-2001. Paris, OECD/IEA, 2003.

KLINK, C.A. Mudança do Clima e a Educação Ambiental in Educação Ambiental \& Mudanças Climáticas: Diálogo necessário num mundo em transição. MMA - Brasílial DF, 104p. 2013.

MARENGO, J.A. Mudanças climáticas globais e seus efeitos sobre a biodiversidade: caracterização do clima atual e definição das alterações climáticas para o território brasileiro ao longo do século XXI Brasília: MMA, 212p. 2006.

MINISTÉRIO DO MEIO AMBIENTE. Mudança Climática. Disponível em < http://www.mma.gov.br/ informma/item/8266>. Acesso em 04 de dezembro de 2017.

TAMAIO, I. Educação Ambiental\& Mudanças Climáticas: Diálogo necessário num mundo em transição. MMA Brasília/DF, 104p. 2013. 